\title{
POST-DIVORCE PATERNAL CUSTODIAL RIGHTS OF UNDERAGE CHILDREN: LEGAL ANTHROPOLOGY REVIEW*
}

\author{
Atik Triratnawati** \\ Department of Anthropology, Faculty of Cultural Sciences, \\ Universitas Gadjah Mada, Yogyakarta \\ Jalan Sosio Yustisia 1, Bulaksumur, Sleman D.I. Yogyakarta 55281
}

\begin{abstract}
This papers discusses the trend of custodial rights of underage children that fall to the fathers after divorce. The Legal Anthropology Study is conducted by interviewing 15 (fifteen) divorced couples wherein custody fell to the fathers. The tendency of granting custody to the fathers is motivated by several factors from the wives: affairs, ill temperaments, neglectful of children, animosity with the in-laws, and the desire to divorce quickly without the burden to care for children. Fathers accept the responsibility as the caregiver of children to show his economic capability; to easily oversee the development of children; to facilitate their daughters when they require custodians for their marriage as well as to provide affections. In caring for children, fathers are assisted by relatives.
\end{abstract}

Keywords: custody, fathers, dispute, children, divorce.

\section{Intisari}

Tulisan ini membahas tren hak asuh anak di bawah umur pasca perceraian jatuh di tangan bapak. Studi Antropologi Hukum dilakukan dengan mewawancara 15 pasangan cerai dengan hak pengasuhan jatuh ke tangan bapak. Kecenderungan pengasuhan anak ke tangan bapak dilatarbelakangi faktor istri: selingkuh, tabiat buruk, penelantaran anak, bermusuhan pada mertua perempuan, ingin cepat bercerai tanpa beban mengasuh anak. Bapak menerima tanggung jawab sebagai pengasuh anak karena ingin menunjukkan bahwa ia mampu secara ekonomi; agar mudah mengawasi tumbuh kembang anak; memudahkan saat anak perempuannya nanti membutuhkan dirinya sebagai wali nikah serta ingin mencurahkan kasih sayang. Bapak mengasuh anak dengan bantuan kerabatnya.

Kata Kunci: pengasuhan, bapak, sengketa, anak, perceraian.

\section{Pokok Muatan}

A. Background 302

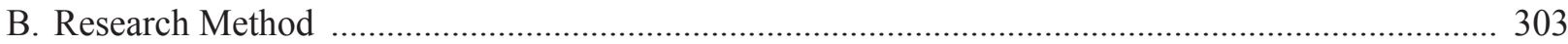

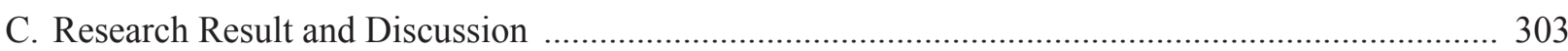

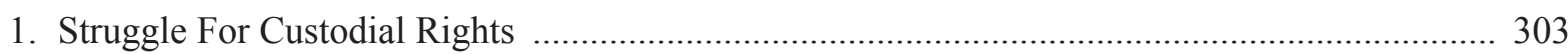

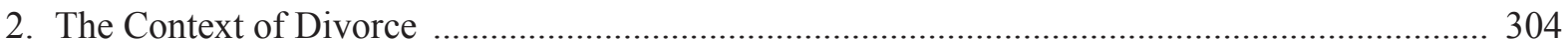

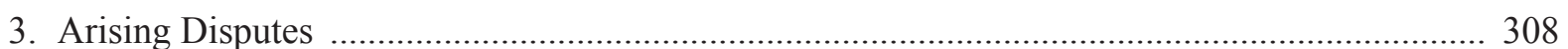

4. Contribution of Relatives on the Caregiving of Underage Children …...................................... 308

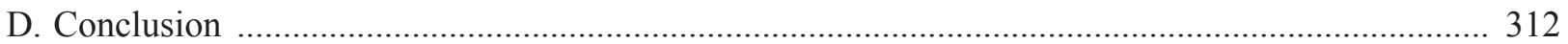

Research Funded by Author, Year 2010/2011.

Correspondence address: atik_triratnawati@yahoo.co.id. 


\section{A. Background}

In the life of a household, the wish of a couple to be united until death do them part is not easy to realize. The relationship of the couple would be subjected to turbulence and shifting dynamics. Conflict, disharmony, fights and loss of attention as well as affection between the husband and wife carries the risk of shattering the marriage, in particular if the couple is incapable of properly managing the conflict. Conflicts between husband and wife often end in divorce. Divorce will result in four outcomes: in relation to the relationship between the wife and husband, alimony, property and custody of the children. ${ }^{1}$ In many cases, the heaviest consequence of divorce falls onto the children as they become victims to the ego of their parents.

In general, marital breakup is followed by complex issues in particular concerning inheritance such as congenital pre-marital wealth, shared wealth, custody of children as well as waning familial relationship. ${ }^{2}$ Custodial rights become the most severe issue to be decided as it involves the heart and feelings whether it is affection, attention and attachment between the parents and the children.

The care of children is intended as the duty of either the husband or the wife to provide clothing, food and shelter, which also includes education and security. The responsibility and care of children (hadhanah) are governed by the norms of Islam which decrees that both parents share the responsibility to care for the needs of the children, whether physically, mentally, academically and spiritually. ${ }^{3}$

Article 105 of Islamic Law Compilation (ILC) provides that the custodial rights of children under the age of 12 fall to the mothers. If the child has become an adult, they may decide between the father and the mother. The ILC states that the age limit of a child to be independent or mature is 21 year old, provided that the child is not physically/ mentally disabled or has married. Although both parents are responsible to care for their children, Islam puts an emphasis on the mothers. The reason is that affection and the education of children are primarily delegated to mothers and mothers are considered to be more social than fathers since they are more knowledgeable in clothes, food, drinks, health and others. ${ }^{4}$ Article 41 of Law on Marriage of Year 1974 mentions that both parents which include the father and the mother have each own obligations to care and educate their children, which is solely for the interest of the children and should there be a dispute between them on the custody of the children then the court has the right to decree its judgment. ${ }^{5}$

In the society of large cities in Indonesia as reported by the newspaper and televised news, in the many cases of divorced celebrities it is the fathers who are granted custodial rights despite the children being underage. Celebrities such as Adjie Massaid (alm.), Anang Hermansyah, Teuku Rafly, Ben Kasyafani, Achmad Dani, Ivan Fadila are cases wherein custodial rights fell onto the hands of the father, though the maternal side likewise fought for custodial rights.

The familial system adopted by an individual does affect post-divorce custodial rights. In patrilineal ethnic groups, the pattern shows that custodial rights fall on male relatives. In the Balinese and Acehnese, custody tends to fall onto male relatives. Whilst the Javanese, who adhere to parental line, are partial to discussion or depending to the judgment of religious court. However, in general the wives desire custodial rights for themselves so that the children would not be neglected. ${ }^{6}$ Consideration of customary norms often

\footnotetext{
Djamil Latif, 1982, Aneka Hukum Perceraian di Indonesia, Ghalia Indonesia, Jakarta, p. 98. Atik Triratnawati, 2011, Aspek Hukum dan Sosial Perlindungan Anak Hasil Cerai, Research Report, Fakultas Ilmu Budaya UGM, p.26. Yaswirman, 2006, Hukum Keluarga Adat dan Islam, Andalas University Press, Padang, p. 247 dan p. 252.

Amiur Nuruddin and Azhari Akmal Tarigan, 2004, Hukum Perdata Islam di Indonesia, Prenada Media, Jakarta, p. 302

Article 41 Indonesia's Law on Marriage of Year 1974 (State Gazzete of 1974 No.1).

Hildred Geertz, 1981, Keluarga Jawa, Grafiti Pers, Jakarta, p.147.
} 
overcomes Islamic ordinances, which provide that the custodial rights of children who are not mumazis would be granted to the mothers. Judges of religious court who decide on the matter may include myriad of considerations before deciding on the dispute on custodial rights of children.

In customary law, the dissolution of marriage is generally caused by: 1 . Adulterous wives; 2 . If one of the parties (husband or wife) is guilty, for example if the husband has left the wife for a prolonged period of time or the wife exhibits disrespectful behavior. ${ }^{7}$ Meanwhile in the elucidation of Law on Marriage No. 1 of Year 1974, Article 39 provides that the reasons that may be used as the basis for divorce are: a. one of the parties has committed adultery or become alcoholic, drug addict, gambler or other conditions that are difficult to cure, $b$. One of the parties have left the other for 2 years continuously without the permission of the party and without a legitimate reason or because of other matter outside their will, c. One of the parties is convicted for 5 years or more severe punishments after marriage is held, $d$. One of the parties commits acts of cruelty or severe abuse that endangers the other, e. One of the parties acquires disability or illness that results in the inability to perform the duties as husband/wife, f. Husband and wife continuously have dispute, conflict or there is no hope for harmony in the household. ${ }^{8}$

Reviewing divorces and custodial rights by using an approach from Legal Anthropology is important considering the pluralism of law. If a legal expert views the law as a tool that controls the society and directly witnesses changes in society, anthropologists emphasize law as the reflection of certain social orders. ${ }^{9}$

Based on the aforementioned analysis, the formulation of problem that arises is as follows: (1) Why do custodial rights of underage children fall onto the fathers?; (2) What are the disputes that arise before custodial rights are granted to the fathers?; (3) Is there contribution of energy and thoughts from the relatives of the father and mother in the process of caring for underage children after divorce?

\section{B. Research Method}

Ethnographic research was conducted on the Javanese communities in DIJ and surrounding areas, by finding cases in which custodial rights of children were granted to the fathers, whereas mothers who were entitled to care for underage children instead conceded custodial rights to their ex-husbands. Interview is conducted to 15 divorced men who acquired custodial rights of their children. Data was gathered in 2011 through interviews conducted in the homes of the informants. Interview was aided by students participating in Legal Anthropology class in the Faculty of Cultural Sciences, Universitas Gadjah Mada, Yogyakarta. Students sought cases of divorce occurring from their domiciles. Interview of the informants was guided by questions that was formulated by the researcher.

\section{Research Result and Discussion 1. Struggle for Custodial Rights}

The length of a marriage does not guarantee harmony between the husband and the wife. The breakdown of marital relationship may happen to anyone regardless the age of the marriage. Data from this research proves that divorce may occur to marriage of any age. From 15 cases of divorce in which custodial rights fell onto the fathers, the age of marriage averages from 1 to 22 . The divorces in general occurred several years ago (less than 5 years at the time of data gathering), although some took place only several months in the past.

Not all cases of paternal custodial rights proceeded seamlessly. Myriad of conflicts or disputes followed through. Conflicts and disputes 
were strengthened another party which was the relatives of the husband or the wife interfered with the issue. From existing cases, shift in custodial rights is commonly found to first belong to the mothers before changing to the fathers. The shift that arises is influenced by the context and the socioeconomic condition of each couple. In one case, the mother initially cared for the child when he was a toddler but after junior high school custodial rights shifted to the father considering the expanding living and educational cost that the mother felt she could no longer afford.

In those 15 cases of divorce, many cases involved struggle for custody from both parties. The struggle for custody is then decided by the court which grants custodial rights to the fathers. The tug of war between the husband and the wife is a constant occurrence except in cases where one party voluntarily concede custodial rights to the party who desires custody with the intention to quickly resolve the dispute.

In general, the assignment of custody is determined by the religious court and district court, therefore both sides must respect the decision of the court. However, in some cases custody is considered based on the principle of kinship, which means that both sides make their decisions voluntarily. In one instance, the wife conceded custody to the husband as she intended to be divorced quickly. As occured in the subsequent SW case:

My wife did not want to care of the child, she even refused. My wife is still young so she was ashamed if she became a widow with a child. She wanted to quickly marry another man.

In 15 cases of divorce, the age and gender of children varied between 1-4, and the gender is evenly distributed between male and female. However there is tendency for the custody of sons to fall onto the fathers as occurred in the case of TR who chose to bring the three of his sons, while the wife allowed it. In some cases, sons were taken care of by the fathers during infancy and after puberty custody was given to the mother and vice versa. The case that occurred to RS is as follows:

RS (husband) is divorced from I (wife), with their son cared for by RS and the infant toddler is cared for by I. After several years, the son chose to go to a high school and resided in the same city as the mother. RS allowed it, and he chose to remain farming in the village.

Divorced couple always complained about the lengthy process of divorce, even consuming much time, energy and cost. The process of divorce is emotionally draining, because the process may drag on from months to years. Aside from accompanied by disputes, changes in the life of the couple would arise post separation including the effect to the children. Children would be confused, sad, angry and disappointed by the situation they are experiencing.

\section{The Context of Divorce}

The context behind the divorce carries huge impact on the care of the children resulting from the marriage. The custody of those who are divorced is not automatically granted to the mothers even if the children are underage, and instead is given to the father of the children desire so. There are several factors in the context of divorce that provides large consequences on the decision of custody. A father who often commits acts of violence whether physical and mental to the mother would cause the children to feel more comfortable in living with the mother. Similarly in the case of adulterous mother, then the father would struggle for the custody of the children as he is concerned that the children will be affected by the behavior of the mother. The cause of divorce is not a factor with singular characteristic, but instead it is complex. There are fundamental reasons, yet there are non-fundamental reasons (supporting factor). Causes of divorce that results in custody falling to the fathers in 15 cases are as follow: 


\section{1) Bad Temperament, Habits, Traits, Character of the Mother}

The role of mothers to the Javanese and Indonesian society is positioned as caregiver, educator and manager of family finance. ${ }^{10}$ The task demands mothers to possess good character, wholehearted affection to the family as well as being able to interact with the relatives of the husbands such as the inlaws and other relatives. However, not all wives are able to position themselves in the task as the ideal wife. There are multiple cases of wives with ill temperament.

Improper maternal characteristics include irritability, neglectful of children, wasteful, querulous Karakter ibu yang buruk seperti pemarah, menyia-nyiakan anak, pemboros, like to fight/quarrel with the husband, especially disobedient to mother in-law and daring to evict her, in many cases such behaviors are generally unacceptable in society especially to the husband. An ideal wife must be respectful and obedient to the husband or the parents and in-laws.

The case in which the wives behaved in improper manner happened to $\mathrm{AB}$ and NT. NT as the wife had higher income than the husband, however she maintained that familial finance is the sole responsibility of the husband. Fights with regard to finance occurred continuously in the beginning, however the problem grew because NT herself is ill mannered. She often yelled at her own parents. The divorce between $\mathrm{AB}$ and NT was supported by the parents of NT who were frustrated by the behavior of their child. In the divorce, the custody of the child fell to $A B$ because he would not allow if their child who was only 5 year old to be with the mother. Psychologically, the mental development of the child would experience disturbance under the care of the mother.
When $\mathrm{AB}$ was not at home, the child was often pinched by NT, thus the child viewed the mother as a villain. The child was also unhappy if the mother often went away with another man. NT then married another man, but in the development of $\mathrm{AB}$ as the father he was no longer able to care for the child due to his career. In the end, the child is now in the care of the grandmother from maternal side

Fathers are concerned about the improper characters and behaviors of mothers as they fear the mothers would abandon the children. Therefore, improper character of the wife as a factor has large impact on the custody of children that falls on the fathers.

\section{2) Low Socioeconomic Factor of The Wives}

The case of D (sewing operator) who had been married to B for 6 years chose to be divorced after the character of the husband who was an alcoholic could not be changed. If $\mathrm{D}$ reminded the husband to not drink, the husband would abuse D. Their daughter who was in the kindergarten was cared for by the mother as decided by the religious court. However after a year D was found out to have physically abused the child so the relatives of $\mathrm{B}$ were adamant that the custody of the daughter should be given to the father. The relatives of B provided many reasons for the custody, inter alia so when the daughter wishes to marry it is easy for her to look for her father as her custodian. However an equally important reason is that the family of B is wealthy therefore it would be an embarrassment for the family if custody fell to the wife who was not as welloff. Furthermore, B as the only male child in the family will receive inheritance if he has a child. The daughter is required to continue the lineage of B. For B himself, the daughter is a prestige for himself as the parent. Based 
on the reasoning, eventually the custody of the daughter is granted to the father although later the daughter was placed in Islamic boarding school as mandated by the family, which is known and respected not only for the wealth but also as a religious family in society.

\section{3) Adulterous Wives}

Infidelity is often the major trigger of conflict between the husband and wife. Infidelity is often the cause of divorce. ${ }^{11}$ In the eyes of society, an adulterous wife has greater consequence than an adulterous husband. Infidelity results in the feeling of betrayal in each party, therefore nullifying the respect between the couple.

From psychological perspective, an adulterous wife is considered to have large impact on the pscyhology of the children. In many cases, the infidelity of the wives result on punishment from the husband and children in the form of the handover of custody to the father. The children are disassociated from the mother and the children often develop hatred to the mother because the mother has become close to another man. Such a case is experienced by SWT who worked in Jakarta, while the wife (RM) stayed in their home village in Purwodadi. Since the wife had an affair, they were divorced. Their daughter who was 6 year old was cared for by the wife. However SWT remarried and watched that his former wife was not able to care for the children, in addition that the economic situation of RM was lacking henceforth the daughter was taken to be cared for by the father.

\section{4) The Wife is Busy With Work}

The case is experienced by $\mathrm{BB}$ who felt that his wife R (civil servant) spent all her time working until late in the night. As the result the three of their children were not close to their mother. Fights often happened due to incompatibility between the two of us. The District Court of Sleman, DIY, decided on the matter of divorce and the three children who were already adults decided to live with the father. BB himself is financially able to provide for the three children, furthermore he wished that his children did not be torn apart so all of them chose to stay with him. After the divorce, BB built another house that is located not far from his ex-wife with the hopes that the children could meet their mother easily.

Similar condition happned to couple $\mathrm{T}$ (driver) and $\mathrm{S}$ (market shopowner). $\mathrm{T}$ was often out of town while S was busy with her work so they met very rarely. Fights often occured due to incompatibility between the two. They split in 1998 and divorce took place in 2003. The three children of theirs chose to live with the father although their provision is a shared responsibility between the father and mother.

\section{5) Wasteful Wife}

Troubled familiar finance may be triggered by wasteful behavior from the wife or liking to go on shopping sprees despite the financial difficulty in the family. Financial problems often cause fights between husband and wife, the fight is even often protracted.

Wasteful lifestyle of the wife is not the primary factor of divorce, instead it is simply a trigger. Such a case is experienced by $\mathrm{S}$ who lived in a separate city from his wife. The husband sent Rp 3 million to Yogyakarta to cover the living cost of the wife and 2 underage children. As the result of the wasteful lifestyle of the wife, the money sent by the husband monthly was never sufficient, even the money $\mathrm{S}$ sent for his mother who

11 Atik Triratnawati, “The Non-Existing and Social Welfare for Children After Parents' Divorce”, Proccedings, The 3th International Graduate Students Conference on Indonesia, The Graduate School UGM, Yogyakarta, 2012, p. 423. 
lived in the same house with the wife was also taken. The wife often quarreled with the mother-in-law, even uttering profanities. S promised to bring the wife and children to the city where he worked. But the promised was not fulfilled. For 2 months the wife ran away with family savings amounting to 19 million. The wife was considered to have neglected the children. As the result, after divorce $\mathrm{S}$ brought the children to the city where he worked, as it turned out that in that city S had married another woman.

The same case is experienced by $\mathrm{AD}$ who worked as an artist, while NN (whose contract was terminated) as the third wife retained her hobby to shop despite difficulties in familial finance. Their livelihood was often supported by the mother-in-law. Their two sons became delinquents, unruly and refused to attend school. Ultimately, NN quarreled with the mother-in-law and evicted her from their home. NN left the family and returned to Ambon. Both parties wished to care for the children, however Civil Archive Office decided that custody would be given to the father. NN returned to her family as her parents wished for it. NN could not get the blessing for her parents for the marriage, therefore the divorce was fully supported by her parents.

6) The Wife is Not Disharmonious with Mother-In-Law

The relationship between wife and mother-in-law in the history of human relationship is often depicted as rising tides. Disharmony between the wife and the motherin-law in many cases may trigger divorce. Rivalry for affection and attention from the husband triggers fights between the wife and mother-in-law. The quarreling parties feel the most entitled for the presence and the wealth of the husband. The wife wishes to control and possess the husband, so does the motherin-law. Such a condition often happens to couples who live with relatives. Considering the housing situation, the frequency of interaction between the wife and motherin-law is incredibly high and the risk for conflict to arise is increased, in particular if the characters of the wife and mother-in-law oppose each other.

\section{7) Wife is Mentally Ill}

Mental illness in Javanese culture often causes stigma for the patient. Mental illness is considered as an inherited illness and the patient would face difficulty in finding a match. In cases wherein the wives suffer mental illnesses after marriage who are then divorced by the husbands, custody falls to the fathers. Though such a case happens in relatively low frequency, the case is experienced by couple G (34 year old) and Yn (29 year old). The couple cohabited without marriage in faraway region, from which arrangement resulted two children, after which marriage was conducted in civil archive. After the birth of the third child, the couple was divorced and lived in separate cities. After the incident wherein the parents of Yn (in-laws of G) passed away, the wife started to exhibit signs of mental illness. The wife was no longer able to care for the children, resulting in abandonment. As the result of the condition, the custody which originally was with the mother was taken over by the father.

8) Wife Enters Into Informal Marriage

The case is experienced by ST (32 year old) who was left by the wife who worked as domestic worker in Malaysia. Originally, marriage took place because the wife was pregnant out of wedlock. Initially ST did not have permanent work, although he often farmed and the wife was a laundry worker to help the lacking familial finance. The wife then decided to work as domestic worker to fix their familial finance. It turned out that after several years, the wife had conducted 
informal marriage with a wealthy Malaysian. ST felt betrayed by the wife so they became divorced. The custody of their fell onto the father because since he was young ( 5 year old) he was left by the mother to Malaysia, therefore it was the father who cared for him. Religious court decided that the father would be the caregiver of the child. The strong emotional bond between the child and the father resulted in inability in ST to part with his son.

Of various reasons behind paternal acquisition of custody, it is apparent that the wife is a prominent factor. Although paternal factor may become a cause however due to the vulnerable position of the wife it is always the wife that is made as the primary factor of divorce.

\section{Arising Disputes}

In the process of divorce, conflict arises not only on the subject of shared wealth but also on the custody of children. Custody is a complicated matter because the love/feeling of the children, father and mother is difficult to divide between them. However considering that the parents have split then there is no option other than granting custody to the father or father. Custody may be rotated between the mother and the father but not both at once. Although rotation of custody is possible, ultimately children will spend a large amount of time only with one of them. From 15 cases of divorce, there are two forms of divorce that arose,${ }^{12}$ with regards to struggle for custody before eventually decided to fall to the fathers.

a. Dispute between individuals. In this regard, both the husband and the wife would maintain their custodial rights over the children, however the matter is then decided by religious court. The aforementioned cases serve as examples that it is the fathers who won the custody of the children. b. Dispute between groups. In such a case, the dispute is originally between the husband and the wife but then one or two parties is assisted by the relatives hence the custody falls on the stronger party whether in authority or wealth, and in general it is the father's side.

Dispute between families are then resolved in amicable manner. The case of $\mathrm{BB}$ in which in the beginning the wife wished to care for the children, eventually proceeded peacefully after the District Court decided that the father was entitled to care for the children, because the children themselves chose to live with the father as opposed to the mother who was always busy with work.

\section{Contribution of Relatives on the Care- giving of Underage Children}

Considering the age of children whose parents are divorced is varied, from underage to adulthood, the resolution varies. There are cases in which at the time of the divorce the children were underage however now they have become adults therefore custody may be shifted because they are entitled to make their decision on living with the father or mother.

From variety of existing case, there is tendency for infants to be cared for by the mother, in relation to the necessity for breast milk, affection, attention as well as maternal gentleness in caring for infants. On the contrary, for children over infanthood in which the care is relatively easier as they no longer breastfeed and have started school, fathers are more inclined to take the role of caregiver. For such reason, religious court considers the age of children when deciding to grant custody to the father.

The paternal acquisition of underage children shows that there is inequality in the role and authority between husband and wife, in which the husband is shown to possess stronger authority.

12 Valerine J.L.Kriekhoff, 1993, Antropologi Hukum Sebuah Bunga Rampai, Yayasan Obor Indonesia, Jakarta, p. 225. 
The role of mothers as custodian of tradition, norm, societal value as well as the role as connector to the next generation is ignored. Not all cases wherein the care of children is given to the fathers proceeded smoothly. In reality, there are various instances where the fathers are found to be incapable of caring for children on their own. Fathers may require assistance as companion in caring for children. Assistance may come from his own relatives or the relatives of the former wives. The role of paternal and maternal relatives is quite substantial in postdivorce caregiving. Oftentimes, although custody has been decided by religious court to fall on the father or mother, in reality the children are not cared by either party but instead be cared for by paternal or maternal grandmother or even other relatives of the father and mother such as older and younger siblings.

In the case that occurred to couple D and B, the child was instead entered into Islamic boarding school after custody was fought over by the father and the father was declared to eligible for custody. Childcare is handed over to religious institution with the intention so that in the future the child will become religious and knowledgeable in the matters of the faith.

Such is the case of $\mathrm{AB}$ and $\mathrm{BH}$ in which in the beginning custody was with the father, however after the child started attending school the intensity of the father's work increased and instead the child was cared for by the grandmother from maternal side. Consideration was given on the fact that the child no longer had a mother (the mother had remarried) so the grandmother felt pity and became willing to care and love her grandchild wholeheartedly.

In the case of $\mathrm{R}$ and I who had been married for 20 years and then divorced, custody fell onto the father (R). However the position of $\mathrm{R}$ was weakened because after the divorce the only child was entrusted to the sibling of his ex-wife. The child communicated with the father through telephone. When $\mathrm{R}$ intended to care for the child himself, he was accused to have kidnapped his own child thus he sought help from Child Protection Commission of Indonesia. He argued that he was fighting for the child from the care of the wife's family because to him the child is the bond to the parents, as well as his fear that under the mother's care the child would be abandoned and would not receive sufficient provision.

Another case is couple $\mathrm{T}$ and $\mathrm{N}$ who have different religions. Although civil archive decided that custody fell onto the father, but remembering that $\mathrm{T}$ did not permanent employment then the custody was decided to also be imposed on the grandmother, and the uncle of both the children of $T$ from the paternal side.

Grandfather and grandmother from the paternal side are also caregivers for their grandchildren. Such is the case experienced by JS who married his wife when her pregnancy entered third trimester. The relatives of the wife was not aware that JS was married because only 4 family members of JS' wife attended the wedding. The marriage did not have the blessing of the wife's family, even the wife's family demanded drowry amounting to $\mathrm{Rp}$ 75 million. Since request for dowry was not fulfilled the child of JS was not recognized by the wife's family. Divorce became the solution underwent by the couple and relatives from the paternal side assumed responsibility on the care of the child.

In the case of SWJ who came from wealthy family, he was evicted by the family of the wife because he was considered lazy and did not have permanent employment. After the divorce, SWJ returned to his family along with his child who was 1,5 year old. The child is cared for by grandmother from the paternal side.

Although dissolution of marriage cuts off the relationship between husband and wife, such is not the case with children. Divorce causes problems to the children in particular regarding the care of children. Decision on custody through religious/district court does not automatically fall onto the party appointed by the court and become the opposite of the court judgment. Compromise, negotiation, as well as amicability (voluntarily) is often attempted by the couple so that children are 
cared for by the party who desires custody.

From cases of divorce found in society, it does not appear that there is a standard pattern for settlement. Each divorce has different resolutions. However, there is tendency that if the divorce is not the result of adultery, but instead domestic violence done by the father to the mother, then the children are inclined to choose the mother as they feel more comfortable with the mother. Children feel secure, protected and mothers are considered to have more patience in raising children. In the case of adultery, if father is the actor, then children are likely to be cared for by the mother. Meanwhile if the mother is adulterous, then the children choose to live with the father. In cases of divorce, it is clear that there is a disproportionate number of cases wherein the wife is blamed, as the result the custody of children is given to the father with the consideration so the children would not be affected by the character of the mother that is considered improper so blame is put on her.

The role of society and local norms also provide significant impacts on the stigma attached on the wife. Strong patrilineal culture in society results in selfishness in men and the women feel increasingly cornered. Meanwhile if the husband is at fault, such as in the case of domestic violence or adultery, the fault is not inflicted solely on him, instead the wife is considered to have taken part for the occurrence of the incident. The wife is considered incompetent in serving the husband, the wife is stubborn or disobedient to the husband.

The phenomenon wherein underage children whose custody according to the Law on Marriage of Year 1974 should be granted to the mothers are instead cared for by the fathers in reality is gaining traction in society. The tendency shows whether in high or lower class of society. One of the reasons is relating to the cause of divorce itself. Therefore the context of divorce determines the custody of the children.

In cases of divorced couples wherein the wives were considered to have committed adultery, the tendency shows that the children would then be cared for by the fathers. Such is intended to prevent the improper character of the mothers from being passed or impact the children, so the children were disassociated from the mothers. Another reason is for the mothers to experience the damage caused by adultery to familial relationship so they deserve the punishment. The punishment delivered by the ex-husbands entails prohibition for the ex-wives from touching the child, or to caring for the child especially in the case of daughters because the exhusbands are concerned that daughters may emulate the behaviors of the mothers with ease. Improper character and behavior of mothers whether due to adultery, inclination to violence, profanities or tendency to neglect children are considered by the fathers as disturbances to the psyche of the children. Psychologically, children would experience stress, threat, fear or discomfort if they are in close proximity to the mothers. For the sake of mental health of the children, they must be disassociated from the mothers.

In Islam wherein familial relation is drawn from the paternal side, the presence of fathers are required until the day their daughters marry. In cases wherein the husbands are adamant to care for their daughters, they argue that if their daughters were to marry then the custodian would not be difficult to find, because they are the custodians, therefore there would not be obstacle relating to custodian during the vow of marriage. Such is often observed that in divorced couples when the daughters wish to marry, finding the whereabouts of the biological father is difficult. Such occurs due to lack of communication after the divorce. As the result, the daughters would have to be married by their brothers or representatives if the whereabouts of the fathers could not be found.

The Islam that is adhered to by majority of Javanese and Indonesians in general results in strong bond between children and parents. Parents are important due to inheritance, custody, witness and custody. Inheritance is determined based on the inheritors and heirs, in this case parents whether fathers or mothers as inheritors and the children 
as heirs. Meanwhile, children, in particular sons, would require witness for marriage. The witness usually includes the father. If the father is divorced, then someone else may become witness, but if the parents are still bound by marriage then the father would become the primary witness. On the contrary, if the daughters wish to marry then the custodian would have to be the father. If the parents are divorced then the whereabouts of the father must be found because only he is entitled to become the custodian on behalf of the bride. If the father could not be located, only then custody could fall onto the siblings of the bride who have reached adulthood. The bride is required to be accompanied by one custodian - who is her birth father - while the groom could appoint anyone to be his witness, although many prioritize their birth fathers as one of the two required witnesses. The importance of attendance and presence of parents in the event of inheritance, custody and witness result in the unbreakable bond between parents and child even if divorce occurs. Such is in the case of inheritance, thus the rights of the children to inheritance would not disappear even if the parents are divorced or deceased.

The combination between the improper character of the wives in addition to the adultery that they commit becomes the primary trigger of divorce in which custody falls onto the fathers. Concern that the improper character of the wives would spread to the child as well as the mental health factor would be stressful to the children if they were cared for by the fathers results in fathers attempting to care for the children.

In a domestic household, adultery should not happen, whether by the husband or the wife, because the children would be victimized. ${ }^{13}$ Furthermore, in the eyes of society, an adulterous wife is considered to be taboo therefore as a mother she would be seen as improper (bad manners). There is assumption in society that adultery committed by the wife is considered an unforgivable act, as the consequence the wife would then be punished by the husband and society by being barred from caring for her children. In addition, there is tendency for adulterous wives to then marry the men they have affairs with therefore many fathers are unwilling to allow their children to live in the same house as a stepfather. The concern of fathers that their children would be abandoned by the mothers or the stepfathers is reasonable, henceforth fathers become even more resolved to raise the children on their own.

Kinship in Java exhibits parental pattern, meaning that the power of relatives from the father and mother is evenly matched, however with regards to divorce in general the children would come with the mothers, especially in underage children. In cases in which custody falls into the fathers, several different interpretations may become applicable. Firstly, in Islam, marriage is a sacred vow between the man and the woman that is equal and filled with love and affection, ${ }^{14}$ therefore emphasizing on the importance of equality. The case of paternal custody of underage children illustrates an unequal relationship because the condition mirrors patriarchal society wherein male authority is stronger than womanhood. The current society is experiencing changes, in particular those residing in cities. The role of fathers as caregivers and educators of children after marriage is no longer seen as a heavy burden and instead considered as awareness that children would be better off being cared by their own parent, though incomplete. The waves of equality of rights and the influence of gender equality brought realization to the men that good single parenthood in which they assume the roles of father and mother is a good choice. Caregiving is no longer restricted to the female gender. Despite itself, there is tendency that fathers are adamant to become caregivers.

Other considerations include the notion that

13 Forum Kajian Kitab Kuning, 2005, Kembang Setaman Perkawinan Analisis Kritis Kitab Uqud Al Lujjayn, Penerbit Buku Kompas, Jakarta, p. 309.

14 Siti Musdah Mulia, "Menuju Hukum Perkawinan Yang Adil: Memberdayakan Perempuan Indonesia”, in Sulistyowati Irianto, et al., 2006, Perempuan dan Hukum, Yayasan Obor Indonesia, Jakarta, p. 146. 
nurturing, educating and caring for children requires substantial cost for clothes, home, education, health and others therefore fathers as breadwinner believe that they are more economically able to shoulder the burden. On the other hand, it is not uncommon for women to fall into economic decline after divorce because they are not laborers or primary breadwinners, so wives oftentimes cannot bear the cost of living of the children on their own.

The value of children to Indonesian society remains substantial, thus a man is adamant that the children would stay with them as consolation after divorce, especially if he is emotionally attached to the children since their childhood. Fathers feel comfortable if they are close to the children. Although assuming the role of both father and mother is not easy, in the eyes of the informant caring for children on their own is considered desirable, because the children would not be neglected. If the children were to be cared by the mothers, then the mothers abandoned them to remarry so the current condition is considered to be the most ideal for the children. Children are assets. Although a father cares both for son and daughter, the value is unchanging. The father hopes that the children would become subservient, be independent and even helpful to the economy of the family. The children themselves would no doubt return the affection to one of the parents who has given the most affection to them. For example, if artists struggled for custody of the children as experienced by Anang Hermansyah, Achmad Dani, Ben Kasyafani dan Tengku Rafly, they may hope that in the future the children would follow their steps as artists thus they would acquire financial gain as parents/managers for their children. In layman terms, fathers would gain advantage in caring for their children because children would observe the person who cares for them and in the future would return the favor by caring for the parents. The father hopes that in the future the children would care more about him than their mother. Future investment from the children would be more significant for the father and not for the mother. Such is the foundation of Javanese adage mikul duwur mendem jero ${ }^{15}$ which means that children must remember the kindness of the parents and forget their laws that is reflected in their daily lives. Children who are cared for and given great affection from the father would in the future care for and return the affection when the father becomes dependent on them. The repayment from the children is expected to be received evenly.

Dispute often accompanies before custody of the child is determined by religious court, even continuing after the court has issued judgment on the custody. Both parties believe that both are equally able to care for their children. Disputes in divorce becomes part of the daily lives in society.

Children are gifts; to the parents and those of pure heart, children are akin to the most precious of jewels. If taught to do good, undoubtedly they would develop in healthy manner and attain happiness both in the world and in afterlife. On the contrary, if they were exposed to wickedness by being abandoned like cattle, undoubtedly they would become ill-fated and perish. ${ }^{16}$

Contribution and role of relatives remain significant in childcare even if custody has been granted to the father. In spite of everything, a man would not able to give proper care on his own. He would require assistance from his relatives to aid with the care of children. Such is the difference between divorce in the West and between the Javanese. In Java, familial bond is maintained and the role of relatives is still necessary despite the divorce. The role of grandmother, grandfather, uncles and aunts from paternal or maternal side is equally significant in the responsibility for the future of the children from the divorce.

\section{Conclusion}

The context of the divorce becomes the reason

Pardi Suratno and Henniy Astiyanto, 2004, Gusti Ora Sare, Adiwacana, Yogyakarta, p. 139

Muhammad Syaifuddin, et al., 2013, Hukum Perceraian, Sinar Grafika, Jakarta, p. 363. 
as to why custody falls onto the fathers. Although religious/district court has the authority to provide judgments on the matter, the history of the divorce and economic capability of one of the divorced parties becomes the basis for consideration. Fathers are often considered to be economically able to provide and care for the children, even in the practice assistance from relatives has significant role in the process of caregiving.

Dispute always arises between the husband and the wife in the beginning of the struggle for custody, although compromise, negotiation, amicable settlement and final judgment from the religious/district court becomes the determinant. Shift of custody also happens on the demand of the child, such as the case of paternal custody shifting to maternal custody and vice versa. The significance of the role of relatives in Javanese society in particular to the case of divorce shows that Javanese society is collectivist, not individualistic as is common in the West. It indicates that the role of family remains significant even after the occurrence of divorce.

\section{REFERENCES}

\section{A. Books}

Falk Moore, Sally, 1978, Law as Process, an Anthropological Approach, Routledge\& Kegan Paul, London.

Forum Kajian Kitab Kuning, 2005, Kembang Setaman Perkawinan Analisis Kritis Kitab Uqud Al Lujjayn, Penerbit Buku Kompas, Jakarta.

Geertz, Hildred, 1981, Keluarga Jawa, Grafiti Pers, Jakarta.

Handayani, C.S., and Novianto, Adhian, 2004, Kuasa Wanita Jawa, LKIS, Yogyakarta.

Irianto, Sulistyowati, et al., 2006, Perempuan dan Hukum, Yayasan Obor Indonesia, Jakarta.

J.L.Kriekhoff, Valerine, 1993, Antropologi Hukum Sebuah Bunga Rampai, Yayasan Obor Indonesia, Jakarta.

Latif, Djamil, 1982, Aneka Hukum Perceraian di Indonesia, Ghalia Indonesia, Jakarta.

Mustari Pide,Suriyaman, 2014, Hukum Adat, Dahulu, Kini dan Akan Datang, Prenada Media, Jakarta

Nuruddin, Amiur and Akmal Tarigan, Azhari, 2004, Hukum Perdata Islam di Indonesia, Prenada Media, Jakarta.
Soimin, Soedharyo, 2002, Hukum Orang dan Keluarga, Sinar Grafika, Jakarta.

Suratno, Pardi and Astiyanto, Henniy, 2004, Gusti Ora Sare, Adiwacana, Yogyakarta.

Syaifuddin, Muhammad, et al., 2013, Hukum Perceraian, Sinar Grafika, Jakarta.

Yaswirman, 2006, Hukum Keluarga Adat dan Islam, Andalas University Press, Padang.

\section{B. Research Report}

Triratnawati, Atik, 2011, Aspek Hukum dan Sosial Perlindungan Anak Hasil Cerai, Research Report, Fakultas Ilmu Budaya UGM.

\section{Proceeding}

Triratnawati, Atik, "The Non-Existing and Social Welfare for Children After Parents' Divorce", Proccedings, The 3th International Graduate Students Conference on Indonesia, The Graduate School UGM, Yogyakarta, 2012.

\section{Government Regulation}

Indonesia's Law on Marriage of Year 1974 (State Gazette of The Republic of Indonesia Year 1974 No.1). 